\title{
The Relationship of Family Size and Composition To Fertility Desires, Contraceptive Adoption and Method Choice in South Asia
}

\begin{abstract}
CONTEXT: Many countries in South Asia, including Nepal, India and Bangladesh, demonstrate a strong cultural preference for sons, which may influence fertility desires and contraceptive use.

METHODS: Demographic and Health Survey data from married, nonpregnant women aged 15-49 who had at least one child were used to examine the relationship of parity and number of sons to reproductive outcomes in Nepal, India and Bangladesh. Outcomes of interest were desire for another child, contraceptive use and type of contraceptive (modern vs. traditional, temporary vs. permanent). Odds ratios and relative risk ratios were calculated using binary and multinomial logistic regression.
\end{abstract}

RESULTS: In general, desire for another child decreased and contraceptive use increased as the number of children and number of sons increased. These associations were more prominent in Nepal and India than in Bangladesh. For example, compared with women who had three daughters and no sons, the odds of contraceptive use among women with two sons and one daughter were 4.8 in Nepal, 3.5 in India and 2.0 in Bangladesh. Within India, the associations of parity and number of sons with reproductive outcomes were generally stronger in northern states than in South India or West Bengal.

CONCLUSIONS: Son preference remains widespread in all three countries and has a major influence on reproductive behavior. Reducing such preference would require a change in social norms and attitudes of the people and an improvement of the status of women.

International Perspectives on Sexual and Reproductive Health, 2009, 35(1):29-38.

\section{By Anuja \\ Jayaraman, Vinod Mishra and Fred Arnold}

Anuja Jayaraman now an independent consultant, was at Macro International, Inc., Calverton, $M D$, USA, when this work was done. Vinod Mishra is director of research and Fred Arnold is vice president-both at Macro International, Inc
A strong cultural preference for sons exists in many countries in East and South Asia. ${ }^{1,2}$ Sons are more prized than daughters in these countries for a variety of social and economic reasons, including their financial and labor contributions to the family, their ability to support their parents and their perpetuation of the family name. ${ }^{3}$ In some countries, especially in South Asia, sons also bring wealth into the family through dowry ${ }^{4}$ and are solely entitled to perform certain religious ceremonies. Son preference may be a result of parents' simply following the societal norm of taking better care of males and ultimately devaluing females. ${ }^{5}$ At the same time, many parents in this region want to have at least one daughter. ${ }^{3}$

Studies from Bangladesh, India, Nepal, Pakistan and Sri Lanka have confirmed the widespread presence of son preference in South Asia and its impact on reproductive attitudes. 3,6 Son preference often translates into discrimination against girls in nutrition, schooling 7,8 and health care, ${ }^{5,9-11}$ all of which can adversely affect their health and well-being, and may even lead to elevated rates of female mortality. ${ }^{1,4,12-14}$ Not all studies have documented such adverse effects: A review of 306 child nutrition surveys failed to find any systematic bias toward female undernutrition, ${ }^{15}$ and an analysis of 41 Demographic and Health Surveys yielded a similar conclusion with respect to stunting, underweight and wasting. ${ }^{16}$ It is important to recog- nize, however, that there are considerable regional differences in son preference within South Asia. For example, son preference is much stronger in the northern and central uplands of India than in the south. ${ }^{17,18}$ Similarly, son preference has been strong in the state of Punjab, where the sex ratio has been particularly imbalanced. ${ }^{5}$ According to the 2001 Census, among children aged 0-6, there were only 798 girls for every 1,000 boys in Punjab, compared with 927 girls per 1,000 boys in India as a whole.

Attaining the desired number of sons and the preferred sex composition within the family can lead to cessation of childbearing, female feticide and, in extreme cases, even female infanticide. ${ }^{19,20}$ A decline in fertility without a corresponding reduction in son preference may lead to increased use of sex-selective abortion or female infanticide. ${ }^{3,17,21-23}$ Recent studies in India have linked son preference to high male-to-female sex ratios at birth, which provide strong evidence of sex-selective abortion. ${ }^{19,24,25}$

As fertility declines, two forces may exert opposing effects on sex ratios. ${ }^{24}$ The first is the parity effect: The survival of girls is expected to improve as the percentage of higher-order births declines, because fewer girls will be unwanted. This effect may result in a reduction in sex bias. The second is the intensification effect: When the desire for children falls at a faster rate than the desire for sons, the effects of son preference on sex-selective fertility behavior 
and sex ratios tend to intensify, ${ }^{17}$ a phenomenon that has been observed in low-fertility societies such as China, Taiwan and South Korea. ${ }^{26,27}$ The result may be an increase in sex bias. These opposing effects may determine the sex differential in the population. ${ }^{24}$ However, one study found that son preference slowed (but did not stop) the fertility decline in Korea, leading the authors to observe that modernization tends to reduce fertility despite the presence of son preference. ${ }^{28}$ A recent study of sex ratios at birth in South Korea suggests that the intensity of son preference decreases as a country develops, primarily because traditional beliefs diminish. ${ }^{29}$ Other modernizing factors, such as education, urbanization and exposure to mass media, also help to reduce preference for sons. ${ }^{17,29}$

Family planning policies in most countries do not explicitly discourage son preference. Even successful programs, such as those in Vietnam, have not been able to reduce gender discrimination or weaken the patriarchal structure of the family. ${ }^{30}$ The success and effectiveness of family planning and reproductive health programs may be limited if families continue to have children until they have their desired number of sons. For example, in India, the number of children in households with girls aged 0-14 is larger than the number of children in households with boys aged $0-14$, indicating that girls tend to live in larger households. ${ }^{31}$ More important, the finding suggests that families continue to have children in order to attain their desired number of sons. This difference in household size is smaller in southern states than elsewhere in India.

High infant and child mortality rates in South Asia, coupled with a strong preference for sons, are generally believed to be responsible for the low prevalence of contraceptive use and high fertility rates in the region. 2,32 However, evidence that son preference influences contraceptive adoption and fertility is not conclusive. On the one hand, some studies have found that son preference is associated with a larger ideal family size ${ }^{17}$ and discourages women of lower parities from using contraceptives, which in turn acts as a barrier to reducing fertility. ${ }^{33}$ On the other hand, data from the Matlab Demographic Surveillance System revealed no evidence that son preference influences contraceptive use in Bangladesh, ${ }^{22}$ and studies have found only minor to modest effects on contraceptive use and fertility in Vietnam ${ }^{34}$ and Nepal. ${ }^{23}$ The authors of the Nepalese study estimated that contraceptive use would increase by only $8 \%$ and fertility would decrease by just $6 \%$ in the absence of son preference.

\section{Current Study}

Given this perspective, we examine how family size and composition affect reproductive behavior in three South Asian countries-Nepal, India and Bangladesh-that are known for strong son preference. ${ }^{3}$ Couples can manipulate the size and sex composition of their families by using a range of contraceptive methods and possibly sex-selective abortion. Using data from recent Demographic and Health Surveys, we analyze whether the desire for another child and the choice of contraceptive method (modern vs. traditional, temporary vs. permanent) differ by parity and the sex composition of surviving children. Although we do not directly examine the relationship between sex preference and fertility, both fertility desires and contraceptive use are important determinants of fertility behavior.

In addition to analyzing data for India as a whole, we pool data for four northern states (Bihar, Madhya Pradesh, Rajasthan and Uttar Pradesh) and four southern states (Andhra Pradesh, Karnataka, Kerala and Tamil Nadu) to examine regional variation within the country. The four northern states ("North India") are characterized by relatively high levels of fertility and low levels of economic growth, whereas fertility is lower and economic growth more rapid in the four southern states ("South India"). * Moreover, we separately analyze data from Punjab, because son preference continues to be strong in this northern state despite declining fertility levels and rapid economic growth, and from West Bengal, to allow comparisons with Bangladesh, which is culturally similar.

The total fertility rates in all three countries have declined since the early 1990s. ${ }^{35-37}$ In Nepal, the rate fell from 4.6 births per woman aged 15-49 in 1993-1995 to 3.1 births in 2003-2005; in India, it decreased from 3.4 births in 1990-1992 to 2.7 births in 2003-2005. In Bangladesh, the total fertility rate has stagnated in recent years; it declined by only 0.4 births per woman between 1991-1993 (3.4) and 2001-2003 (3.0). Fertility has already fallen below replacement level in Punjab (1.9 in 2003-2005) and West Bengal (1.6 in 2003-2005).

Contraceptive prevalence among married women is similar in Bangladesh (58\%) and India (56\%), but it is somewhat lower in Nepal (48\%). ${ }^{35-37}$ The contraceptive method mix differs substantially among the three countries for married, nonpregnant women. In India, female sterilization continues to dominate the method mix, accounting for two-thirds of use. Female sterilization is also the most prevalent method in Nepal (38\%), but the injectable (21\%) and male sterilization (13\%) are also relatively common. On the other hand, almost one half of contraceptive users in Bangladesh rely on the pill (45\%), followed by traditional methods (19\%) and the injectable (17\%).

\section{DATA AND METHODS}

\section{Sample and Variables}

The data for analysis are from the 2006 Nepal Demographic and Health Survey, the 2005-2006 India National Family Health Survey ${ }^{\dagger}$ and the 2004 Bangladesh Demographic and Health Survey, each of which collected data from a nationally representative sample of households. The analysis here is restricted to currently married, nonpregnant women aged 15-49 with at least one living

*We use the terms "North India" and "South India" for convenience; they are not meant to correspond to any official geographical classification.

†The National Family Health Survey is a Demographic and Health Survey that was coordinated by the International Institute for Population Sciences, Mumbai, with technical assistance from Macro International, Inc. 
child-6,950 in Nepal, 75,162 in India and 8,864 in Bangladesh. Within India, the analysis includes 16,568 women from the four northern states, 14,146 from the four southern states, 2,315 from Punjab and 4,296 from West Bengal. Details on the survey procedures and sampling design are provided in individual survey reports. ${ }^{35-37}$

We categorize women by the number of living children and number of sons at the time of the survey: parity $1(0$ or 1 son), parity 2 ( 0,1 or 2 sons), parity $3(0,1,2$ or 3 sons), and parity 4 or higher ( $0,1,2$, or 3 or more sons). This is the primary predictor variable in our analysis.

All three surveys asked currently married, nonpregnant women about their desire for a (or another) child and current contraceptive use. We focus on four outcomes: desire for another child (yes or no); current contraceptive use (yes or no); current use of a modern or traditional method (none, using a modern method or using a traditional method); and current use of a temporary or permanent method (none, using a temporary method or using a permanent method). We categorized the IUD, pill, injectable, implant, male and female condoms, and male and female sterilization as modern methods, while periodic abstinence, rhythm, safe period, folk methods, withdrawal and others were classified as traditional methods. * Male and female sterilization were considered permanent methods, and all other methods were classified as temporary.

In the absence of sex-selective abortion and sex-selective cessation of childbearing, sex composition within a population at any given parity is biologically determined. Thus, the associations between a family's sex composition and contraceptive use (as well as method choice) should not be confounded by factors that are known to influence these outcomes, such as education, wealth and media exposure. However, given that sex-selective abortion and sex-selective cessation of childbearing are prevalent in these countries and that these practices are associated with socioeconomic factors, we need to control for these variables. ${ }^{38}$ Therefore, the adjusted models in our multivariate analyses controlled for mother's educational level (no education, primary, secondary or higher), current work status (working, not working), media exposure to family planning messages in the past few months (exposed, not exposed), residence (urban, rural), household wealth and participation in household decision making. Media exposure refers to having heard or seen family planning messages on the radio, on television or in newspapers in the past few months. For the household wealth measure, each country's DHS sample was divided into quintiles on the basis of housing characteristics and household ownership of assets; details on the calculation are available elsewhere. ${ }^{37}$ Final-

*The specific modern and traditional methods used in each country varied. In Bangladesh, the modern methods used were the IUD, pill, implant, injectable, male condom, and male and female sterilization; traditional methods were periodic abstinence, withdrawal and others. In India, modern methods were the IUD, pill, injectable, male and female condoms, and male and female sterilization; traditional methods were rhythm, safe period, withdrawal and folk methods. In Nepal, modern methods were the IUD, pill, injectable, implant, male condom, and male and female sterilization; traditional methods were rhythm, withdrawal and folk methods.
TABLE 1. Percentage distribution of married, nonpregnant women aged 15-49 with at least one child, by selected characteristics, according to country and region, Nepal Demographic and Health Survey (2006), India National Family Health Survey (2005-2006) and Bangladesh Demographic and Health Survey (2004)

\begin{tabular}{|c|c|c|c|c|c|c|c|}
\hline \multirow[t]{2}{*}{ Characteristic } & \multirow{2}{*}{$\begin{array}{l}\text { Nepal } \\
(\mathrm{N}=6,950)\end{array}$} & \multicolumn{5}{|l|}{ India } & \multirow{2}{*}{$\begin{array}{l}\text { Bangladesh } \\
(\mathrm{N}=8,864)\end{array}$} \\
\hline & & $\begin{array}{l}\text { All } \\
(\mathrm{N}= \\
75,162)\end{array}$ & $\begin{array}{l}\text { North } \\
\text { India } \\
(\mathrm{N}= \\
16,568)\end{array}$ & $\begin{array}{l}\text { South } \\
\text { India } \\
(\mathrm{N}= \\
14,146)\end{array}$ & $\begin{array}{l}\text { Punjab } \\
(\mathrm{N}= \\
2,315)\end{array}$ & $\begin{array}{l}\text { West } \\
\text { Bengal } \\
(\mathrm{N}= \\
4,296)\end{array}$ & \\
\hline \multicolumn{8}{|l|}{ Parity/no. of sons } \\
\hline Parity $1: 0$ sons & 8 & 8 & 7 & 8 & 6 & 11 & 10 \\
\hline Parity 1: 1 son & 9 & 9 & 7 & 10 & 11 & 14 & 11 \\
\hline Parity 2: 0 sons & 4 & 5 & 3 & 8 & 2 & 6 & 5 \\
\hline Parity 2: 1 son & 13 & 17 & 11 & 24 & 20 & 18 & 14 \\
\hline Parity 2: 2 sons & 10 & 10 & 7 & 12 & 13 & 10 & 8 \\
\hline Parity 3: 0 sons & 2 & 2 & 1 & 3 & 1 & 2 & 2 \\
\hline Parity 3: 1 son & 9 & 8 & 7 & 9 & 10 & 8 & 8 \\
\hline Parity 3: 2 sons & 10 & 11 & 12 & 9 & 14 & 8 & 9 \\
\hline Parity 3: 3 sons & 3 & 3 & 3 & 3 & 3 & 3 & 2 \\
\hline Parity $\geq 4: 0$ sons & 1 & 1 & 1 & 1 & 0 & 1 & 1 \\
\hline Parity $\geq 4: 1$ son & 8 & 6 & 7 & 3 & 5 & 5 & 6 \\
\hline Parity $\geq 4$ : 2 sons & 11 & 10 & 15 & 5 & 9 & 7 & 10 \\
\hline Parity $\geq 4: \geq 3$ sons & 12 & 11 & 20 & 4 & 5 & 8 & 14 \\
\hline \multicolumn{8}{|l|}{ Education } \\
\hline None & 65 & 48 & 65 & 37 & 36 & 42 & 43 \\
\hline Primary & 16 & 15 & 12 & 18 & 16 & 22 & 30 \\
\hline$\geq$ secondary & 19 & 36 & 23 & 45 & 48 & 36 & 27 \\
\hline \multicolumn{8}{|l|}{ Residence } \\
\hline Urban & 15 & 31 & 23 & 38 & 36 & 29 & 22 \\
\hline Rural & 85 & 69 & 77 & 62 & 64 & 71 & 78 \\
\hline \multicolumn{8}{|l|}{ Employed } \\
\hline No & 25 & 62 & 65 & 55 & 80 & 71 & 79 \\
\hline Yes & 75 & 38 & 35 & 45 & 20 & 29 & 21 \\
\hline \multicolumn{8}{|l|}{ Wealth quintile } \\
\hline Lowest & 18 & 18 & 26 & 8 & 1 & 24 & 20 \\
\hline Second & 20 & 19 & 24 & 16 & 6 & 25 & 20 \\
\hline Middle & 21 & 20 & 19 & 26 & 13 & 20 & 20 \\
\hline Fourth & 20 & 21 & 17 & 27 & 28 & 17 & 21 \\
\hline Highest & 21 & 22 & 15 & 23 & 51 & 14 & 20 \\
\hline \multicolumn{8}{|l|}{ Media exposure } \\
\hline No & 28 & 43 & 49 & 35 & 33 & 43 & 58 \\
\hline Yes & 72 & 57 & 51 & 65 & 67 & 57 & 42 \\
\hline \multicolumn{8}{|c|}{$\begin{array}{l}\text { Participates in } \\
\text { household decisions }\end{array}$} \\
\hline No & 69 & 66 & 70 & 67 & 48 & 58 & 75 \\
\hline Yes & 31 & 34 & 30 & 33 & 52 & 42 & 25 \\
\hline Total & 100 & 100 & 100 & 100 & 100 & 100 & 100 \\
\hline
\end{tabular}

ly, women were considered to be participating in household decision making if they made decisions by themselves regarding any of the following: their own health care, large household purchases or visits to family or relatives.

\section{Analyses}

The study used descriptive and multivariate statistical methods. After describing the sample, we present levels of fertility desire, current contraceptive use, use of modern and traditional methods, and use of temporary and permanent methods for each country and for regions within India by number of living children and number of sons. We then present adjusted odds ratios for associations of number of children and number of sons with each of the 


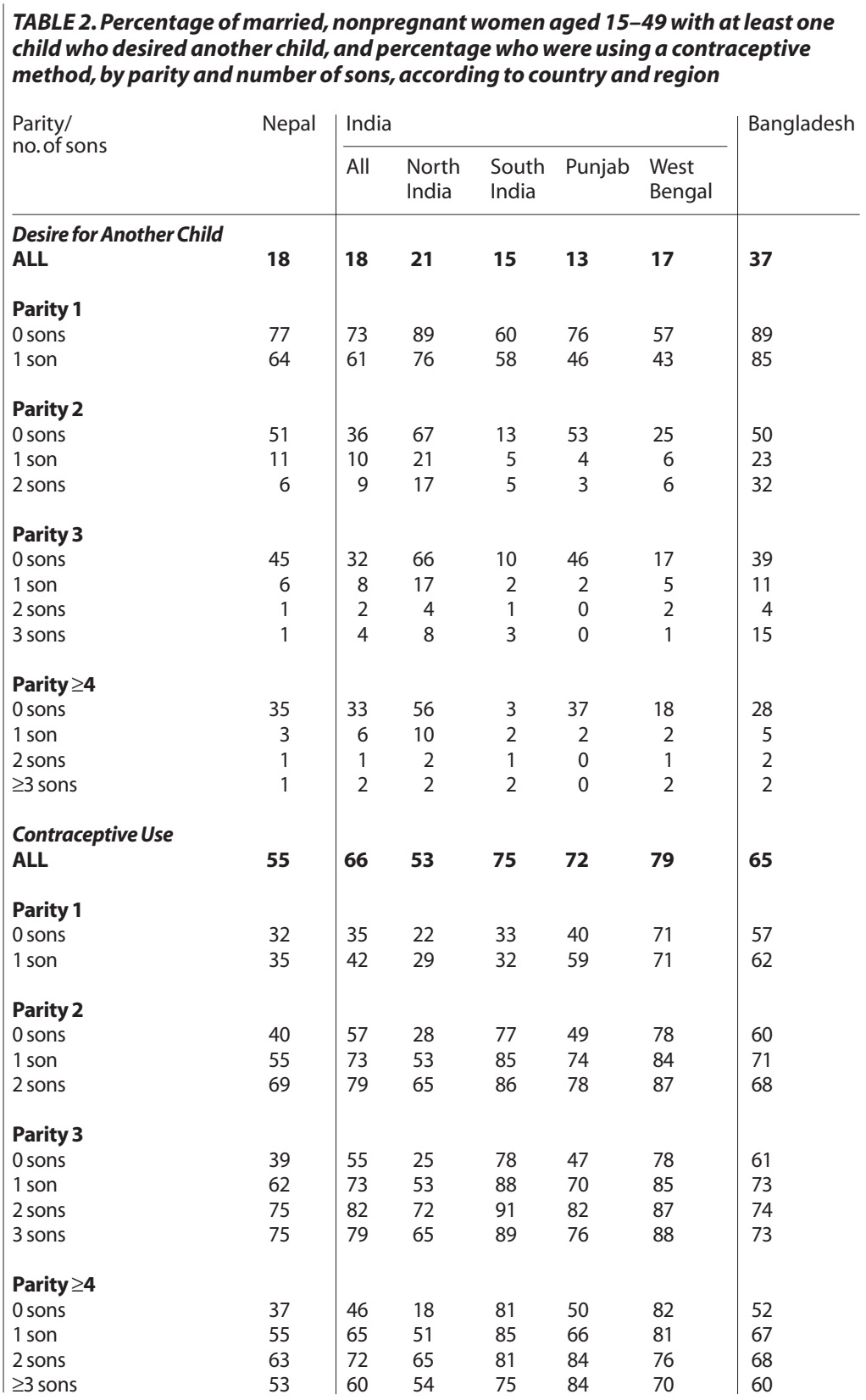

four outcome variables. Logistic regression was used to estimate odds ratios for the binary variables; multinomial logit models were used to compare women using modern or traditional methods with those not using any method, and women using temporary or permanent methods with those not using any method. For all but one of the dependent variables, we estimated separate models for each of the four parity categories; the exception is desire for another child, for which we used three parity categories ( 1 , 2 , or 3 or more). The analysis used sampling weights and accounted for clustering in the survey design.

\section{RESULTS}

For all countries and regions except North India, the proportion of women with one child who had a son was greater than the proportion who had a daughter, although the differences were generally small (Table 1, page 31 ). Among women with two children, the proportion with two sons was greater than the proportion with two daughters in all three countries and all regions of India. The proportion of women with two sons and one daughter was generally greater than that with two daughters and one son, although this was not the case in South India and West Bengal. Differences in sex composition were generally more pronounced in North India than South India.

Close to two-thirds (65\%) of respondents in Nepal and slightly fewer than half (48\%) of those in India had no education. Within India, women in the north were more likely to be uneducated (65\%) than those in South India (37\%), Punjab (36\%) or West Bengal (42\%). The proportion in Bangladesh (43\%) was about the same as in nearby West Bengal. Only 19\% of women in Nepal and 23\% of those in North India had a secondary or higher level of education.

In all three countries, a large majority of women lived in rural areas. In Nepal, only $15 \%$ of women were living in urban areas. The proportion of women who reported working was higher in Nepal (75\%) than in India (38\%) or Bangladesh (21\%). Within India, the proportion of women who were working was highest in South India (45\%). Small proportions of women in South India (8\%) and Punjab (1\%) lived in the poorest quintile of Indian households. Seventy-two percent of women in Nepal, 57\% of those in India and $42 \%$ of those in Bangladesh had been exposed to family planning messages on the radio, on television or in the print media in the last few months. Women's participation in household decision making was low in all three countries: Only one in four women in Bangladesh and one in three women in Nepal and India reported participating in at least one of the three types of major household decisions. In India, greater proportions of women in Punjab (52\%) and West Bengal (42\%) participated in household decision making than in North (30\%) or South India (33\%).

\section{Fertility Desires}

Overall, 18\% of married, nonpregnant women aged 15-49 in Nepal and India and 37\% of those in Bangladesh wanted to have another child (Table 2). The proportion desiring another child was higher in North India (21\%) than in the other Indian regions (13-17\%), which is consistent with the higher fertility levels in North India.

In general, for each country and region, the proportion of women desiring another child decreased with increasing parity. Moreover, at any given parity, the proportion of women desiring another child decreased as the number of sons increased. For example, among women with two children in Nepal, $51 \%$ of those with two daughters wanted to have another child, compared with only $6 \%$ of women with two sons. In Bangladesh, the proportion of women who wanted another child was higher among women with two sons and no daughters (32\%) than among those with one son and one daughter (23\%), suggesting a desire to have at least one child of each sex. Similarly, among 
TABLE 3. Percentage of married, nonpregnant women aged 15-49 with at least one child who were using a modern or traditional contraceptive method, by parity and number of sons, according to country and region

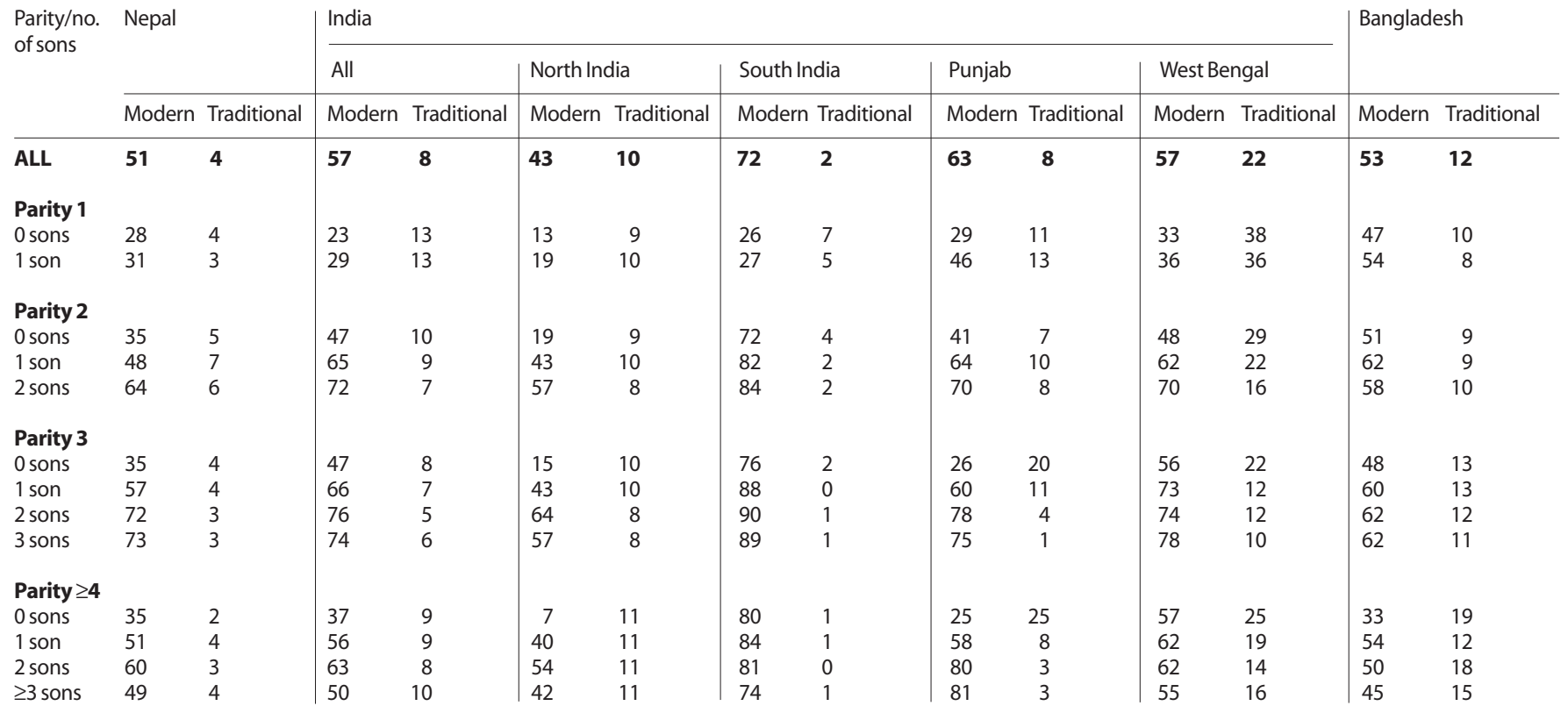

Note: Modern methods are the IUD, pill, injectable, implant, male and female condoms, and male and female sterilization; traditional methods are periodic abstinence, rhythm, safe period, folk methods and withdrawal.

women with three children in Bangladesh and India (as well as in North and South India), the desire for another child was greater among women with three sons than among women with two sons and one daughter. For example, in Bangladesh, 4\% of women with two sons and one daughter wanted another child, compared with 15\% of those with three sons. In Punjab, almost no respondents with three or more children wanted another child if they had two or more sons, whereas $46 \%$ of women with three children and $37 \%$ with four or more children wanted another child if they did not have any sons.

\section{Contraceptive Use}

Overall, the level of contraceptive use was lowest in Nepal (55\%) and highest in India (66\%; Table 2). Within India, the rate was highest in West Bengal (79\%), followed by South India (75\%) and Punjab (72\%), and lowest in North India (53\%). In general, women without a son were less likely to be using a family planning method than those who had at least one son. At each parity, contraceptive use increased as the number of sons increased from zero to two, and then leveled off or declined. The increase in Nepal, India, North India and Punjab was steeper than the increase in South India, West Bengal or Bagladesh. Interestingly, at each parity, a considerable proportion of women reported using contraceptives even when they had no sons; in Bangladesh and West Bengal, more than half of women with no sons reported using contraceptives at each parity. In South India, four in five women with two or more children were using contraceptives. Among women with at least four children, those with two sons had higher levels of contraceptive use than did women with three or more sons, except in Punjab.

The relationship of parity and number of sons to modern method use followed a similar pattern (Table 3). Thus, in Nepal and India, the prevalence of modern method use at each parity increased with the number of living sons, peaked among women with two sons and then plateaued or declined somewhat among women with three or more sons. The same held for all four regions within India, although the proportion of women using modern methods was much lower in North India than in the other regions (43\% vs. $57-72 \%$ ).

In Bangladesh, there was no obvious pattern. For example, among women with two children, the prevalence of modern contraceptive use was slightly lower among women with two sons and no daughters (58\%) than among women with one son and one daughter (62\%). At parity 3, use was similar among women with one, two or three sons (60-62\%); at higher parities, use peaked among women with one son (54\%) and then declined.

Overall, the use of traditional methods was much lower than that of modern methods in all three countries. The proportion of women relying on traditional methods was much higher in Bangladesh and West Bengal than in other regions or countries. In West Bengal, a little more than one in five women $(22 \%)$ relied on traditional methods, and the proportion declined from parity 1 to parity 3. In other regions and countries, traditional methods were not systematically related to parity or number of sons.

Permanent methods (female and male sterilization) were used much more widely in India and Nepal than in Bangladesh (Table 4). In India and Nepal, there was a clear shift toward permanent methods at parities 2 and 3 as the 


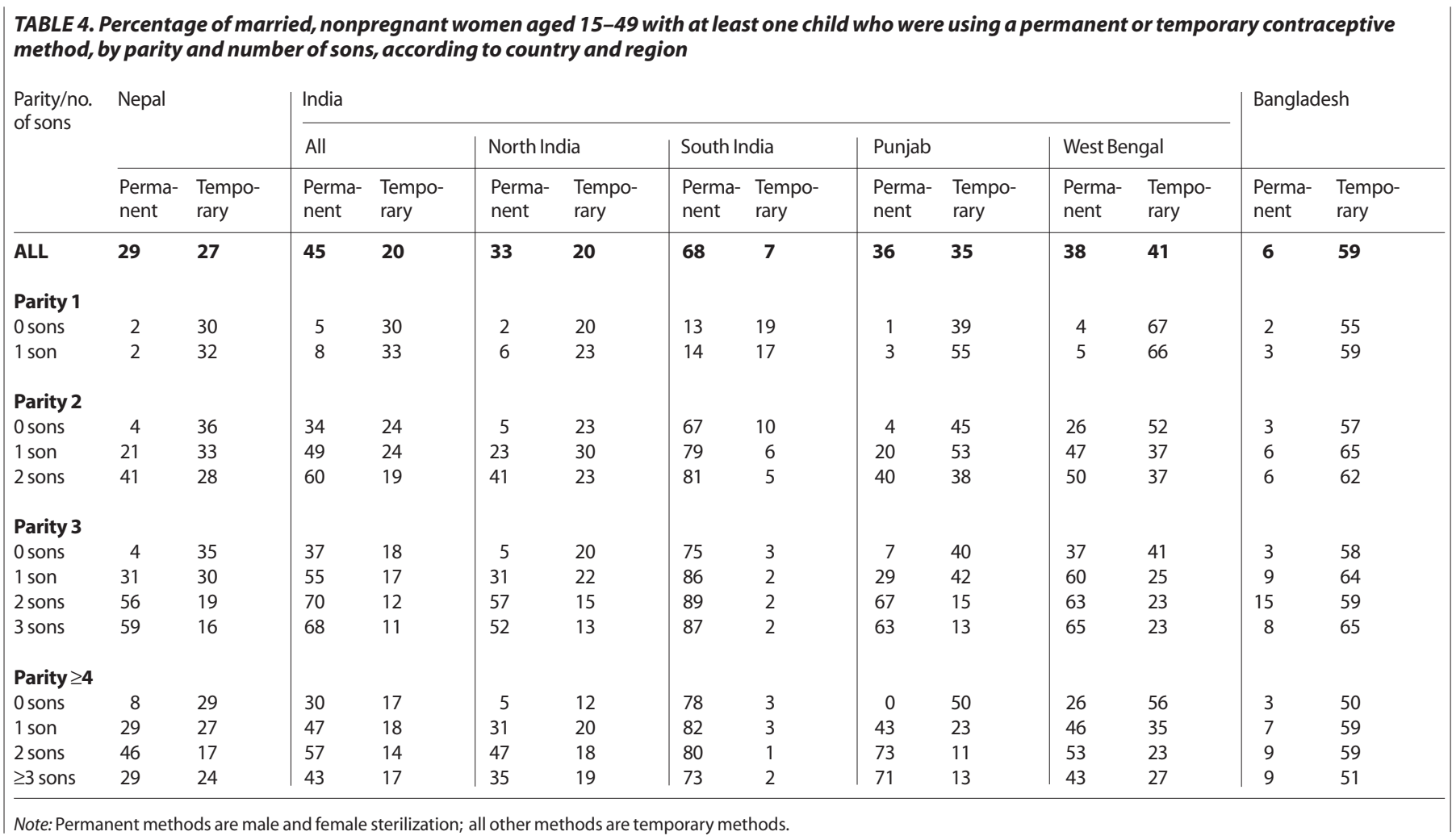

Note: Permanent methods are male and female sterilization; all other methods are temporary methods.

number of sons increased. For example, among Nepalese women who had three children, only $4 \%$ of those with no sons were using a permanent method, compared with $31 \%$ of those with one son, $56 \%$ of those with two sons and $59 \%$ of those with three sons. In Bangladesh, temporary methods were far more prevalent than permanent methods across all parities.

Contraceptive use rates also differed by residence (urban vs. rural), education, household wealth, media exposure and other factors (not shown). The differences by

\begin{tabular}{|c|c|c|c|c|c|c|c|}
\hline \multirow{2}{*}{$\begin{array}{l}\text { Parity/no. } \\
\text { of sons }\end{array}$} & \multirow[t]{2}{*}{ Nepal } & \multicolumn{5}{|l|}{ India } & \multirow[t]{2}{*}{ Bangladesh } \\
\hline & & All & $\begin{array}{l}\text { North } \\
\text { India }\end{array}$ & $\begin{array}{l}\text { South } \\
\text { India }\end{array}$ & Punjab & $\begin{array}{l}\text { West } \\
\text { Bengal }\end{array}$ & \\
\hline Parity 1 & $(\mathrm{~N}=1,222)$ & $(\mathrm{N}=13,564)$ & $(\mathrm{N}=2,364)$ & $(\mathrm{N}=2,628)$ & $(\mathrm{N}=396)$ & $(\mathrm{N}=1,185)$ & $(\mathrm{N}=1,883)$ \\
\hline No son (ref) & 1.00 & 1.00 & 1.00 & 1.00 & 1.00 & 1.00 & 1.00 \\
\hline 1 son & $0.51^{* *}$ & $0.58^{* *}$ & $0.38^{* *}$ & 0.92 & $0.26^{* *}$ & $0.58^{* *}$ & $0.65^{* *}$ \\
\hline Parity 2 & $(\mathrm{~N}=1,796)$ & $(\mathrm{N}=24,222)$ & $(\mathrm{N}=3,889)$ & $(\mathrm{N}=6,158)$ & $(\mathrm{N}=818)$ & $(\mathrm{N}=1,469)$ & $(\mathrm{N}=2,393)$ \\
\hline 0 sons (ref) & 1.00 & 1.00 & 1.00 & 1.00 & 1.00 & 1.00 & 1.00 \\
\hline 1 son & $0.07^{* *}$ & $0.19^{* *}$ & $0.09^{* *}$ & $0.35^{* *}$ & $0.03^{* *}$ & $0.20^{* *}$ & $0.27^{* *}$ \\
\hline 2 sons & $0.03^{* *}$ & $0.17^{* *}$ & $0.07^{* *}$ & $0.38^{* *}$ & $0.02^{* *}$ & $0.22^{* *}$ & $0.44^{* *}$ \\
\hline Parity $\geq 3$ & $(\mathrm{~N}=3,930)$ & $(\mathrm{N}=37,140)$ & $(\mathrm{N}=10,290)$ & $(\mathrm{N}=5,309)$ & $(\mathrm{N}=1,101)$ & $(\mathrm{N}=1,642)$ & $(\mathrm{N}=4,585)$ \\
\hline O sons (ref) & 1.00 & 1.00 & 1.00 & 1.00 & $\dagger$ & 1.00 & 1.00 \\
\hline 1 son & $0.06^{* *}$ & $0.17^{* *}$ & $0.08^{* *}$ & $0.31^{* *}$ & $\dagger$ & $0.17^{* *}$ & $0.20^{* *}$ \\
\hline$\geq 2$ sons & $0.01 * *$ & $0.06^{* *}$ & $0.01 * *$ & $0.22^{* *}$ & $\dagger$ & $0.07^{* *}$ & $0.07^{* *}$ \\
\hline
\end{tabular}

** $\mathrm{p}<.01$. + Odds ratios for parity $\geq 3$ are not shown for Punjab because fewer than 25 women with two or more sons desired another child. Notes: Model controls for maternal education, employment, media exposure to family planning messages, residence, wealth quintile and participation in household decision making. ref=reference category. parity and number of sons tended to be narrower among urban, wealthier and better educated women than among rural, poorer and less educated women.

\section{Multivariate Analyses}

- Fertility desires. The associations of family size and number of sons with the desire for another child were similar in unadjusted models (not shown) and adjusted models (Table 5) in all three countries, indicating that the relationships were largely independent of socioeconomic factors. To ensure an adequate number of cases at each parity, we combined parities of 3 and higher in the multivariate analysis. In addition, because only a very small proportion of Punjabi women with three or more children desired another child if they already had at least two sons, we present results for parities 1 and 2 only.

Across all parities, the desire to have another child generally declined as the number of sons increased. At parity 1 , women with a son had lower odds of wanting another child than women who had a daughter in every country and region except South India. For women with two children, the odds ratios were significantly reduced for all countries and regions among both women with one son (0.03-0.35) and those with two sons (0.02-0.44). Similarly, among women with three or more children, those with one (0.06-0.31) or two sons (0.01-0.22) were less likely than those with no sons to desire another child, and the odds ratios declined as the number of sons increased. - Contraceptive use. The associations of family size and number of sons with contraceptive use were similar in unadjusted models (not shown) and adjusted models (Table 
6). With a few exceptions, the adjusted odds of contraceptive use tended to increase as the number of sons increased, peaking among women with two sons and then declining somewhat among women with three or more sons. An exception is Nepal, where at parity 3, the odds of contraceptive use were highest among women with three sons (5.5)

The associations of parity and number of sons with contraceptive use were strongest in Nepal, followed by India and Bangladesh. At parity 3, for example, the odds of contraceptive use among women with two sons relative to those with no sons were 4.8 in Nepal, 3.5 in India and 2.0 in Bangladesh. Within India, the odds of contraceptive use varied by region and tended to be higher in magnitude in North India than in the other regions (especially South India and West Bengal, where the association was not statistically significant for some or most parities). In Punjab, the odds of contraceptive use were elevated among women with sons at parities 1 and 2. At parity 3, only women with two sons had significantly higher odds of contraceptive use than those with no sons, and among women with at least four children, only those with two or more sons were more likely than women without sons to be using contraceptives.

- Modern and traditional methods. Multinomial logit models revealed that at most parities in all three countries, the relative risk ratio for using a modern contraceptive method (relative to no use) was higher for women with sons than for women without sons (Table 7). For example, among women with three children, the relative risk of modern method use was elevated among women with one son (2.0-2.4), those with two sons (2.1-5.2) and those with three sons (2.1-5.7). The relative risk ratio for using a traditional method tended to increase with the number of
TABLE 6. Adjusted odds ratios from logistic regression to identify associations of parity and number of sons with contraceptive use, according to country and region

\begin{tabular}{|c|c|c|c|c|c|c|c|}
\hline \multirow{2}{*}{$\begin{array}{l}\text { Parity/no. } \\
\text { of sons }\end{array}$} & \multirow[t]{2}{*}{ Nepal } & \multicolumn{5}{|l|}{ India } & \multirow[t]{2}{*}{ Bangladesh } \\
\hline & & All & $\begin{array}{l}\text { North } \\
\text { India }\end{array}$ & $\begin{array}{l}\text { South } \\
\text { India }\end{array}$ & Punjab & $\begin{array}{l}\text { West } \\
\text { Bengal }\end{array}$ & \\
\hline Parity 1 & $(\mathrm{~N}=1,222)$ & $(\mathrm{N}=13,588)$ & $(\mathrm{N}=2,364)$ & $(\mathrm{N}=2,640)$ & $(\mathrm{N}=396)$ & $(\mathrm{N}=1,185)$ & $(\mathrm{N}=1,884)$ \\
\hline 0 sons (ref) & 1.00 & 1.00 & 1.00 & 1.00 & 1.00 & 1.00 & 1.00 \\
\hline 1 son & 1.19 & $1.26^{* *}$ & $1.47^{* *}$ & 0.98 & $2.07^{* *}$ & 1.15 & $1.25^{*}$ \\
\hline Parity 2 & $(\mathrm{~N}=1,797)$ & $(\mathrm{N}=24,250)$ & $(\mathrm{N}=3,892)$ & $(\mathrm{N}=6,167)$ & $(\mathrm{N}=818)$ & $(\mathrm{N}=1,469)$ & $(\mathrm{N}=2,393)$ \\
\hline 0 sons (ref) & 1.00 & 1.00 & 1.00 & 1.00 & 1.00 & 1.00 & 1.00 \\
\hline 1 son & $1.97^{* *}$ & $1.97^{* *}$ & $2.96^{* *}$ & $1.59 * *$ & $3.07^{* *}$ & 1.29 & $1.54^{* *}$ \\
\hline 2 sons & $3.54^{* *}$ & $2.70^{* *}$ & $4.96^{* *}$ & $1.76^{* *}$ & $4.20^{* *}$ & $1.75^{* *}$ & $1.41^{* *}$ \\
\hline Parity 3 & $(\mathrm{~N}=1,638)$ & $(\mathrm{N}=17,949)$ & $(\mathrm{N}=3,909)$ & $(\mathrm{N}=3,335)$ & $(\mathrm{N}=641)$ & $(\mathrm{N}=843)$ & $(\mathrm{N}=1,864)$ \\
\hline 0 sons (ref) & 1.00 & 1.00 & 1.00 & 1.00 & 1.00 & 1.00 & 1.00 \\
\hline 1 son & $2.34^{* *}$ & $2.04 * *$ & $3.52^{* *}$ & $1.95 * *$ & 2.77 & 1.56 & $1.91^{* *}$ \\
\hline 2 sons & $4.81^{* *}$ & $3.50^{* *}$ & $7.92^{* *}$ & $2.96^{* *}$ & $4.90^{*}$ & 1.53 & $1.99 * *$ \\
\hline 3 sons & $5.49^{* *}$ & $3.18^{* *}$ & $5.93^{* *}$ & $2.36^{* *}$ & 3.40 & 1.94 & $1.83^{* *}$ \\
\hline Parity $\geq 4$ & $(\mathrm{~N}=2,293)$ & $(\mathrm{N}=19,232)$ & $(\mathrm{N}=6,385)$ & $(\mathrm{N}=1,980)$ & $(\mathrm{N}=460)$ & $(\mathrm{N}=799)$ & $(\mathrm{N}=2,723)$ \\
\hline 0 sons (ref) & 1.00 & 1.00 & 1.00 & 1.00 & 1.00 & 1.00 & 1.00 \\
\hline 1 son & $2.27^{* *}$ & $1.87^{* *}$ & $4.03 * *$ & 1.40 & 1.80 & 1.03 & $1.67^{*}$ \\
\hline 2 sons & $3.61^{* *}$ & $2.63^{* *}$ & $7.52^{* *}$ & 1.23 & $4.79^{*}$ & 0.84 & $1.75^{* *}$ \\
\hline$\geq 3$ sons & $2.74^{* *}$ & $1.69^{* *}$ & $5.27^{* *}$ & 0.85 & $5.58^{*}$ & 0.66 & 1.26 \\
\hline
\end{tabular}

${ }^{*} \mathrm{p}<.05$. ${ }^{* *} \mathrm{p}<.01$. Notes: Model controls for maternal education, employment, media exposure to family planning messages, residence, wealth quintile and participation in household decision making. The lowest three wealth quintiles are combined for $\mathrm{Nepal}$, South India and Punjab because the number of observations for those quintiles is small. ref=reference category.

sons in India, but not in Nepal and Bangladesh. Within India, the associations of parity and number of sons with modern method use was much stronger in North India and Punjab than in South India or West Bengal (not shown). However, for traditional methods, the associations were positive and significant only in North India. As in the case of Bangladesh, parity and number of sons had no clear relationship to traditional method use in West Bengal, despite the relatively high prevalence of traditional methods.

- Permanent and temporary methods. At each parity in all

TABLE 7. Adjusted relative risk ratios from multinomial logit regression to identify associations of parity and number of sons with contraceptive use, by method category, versus no use, according to country and region

\begin{tabular}{|c|c|c|c|c|c|c|c|c|c|c|c|c|}
\hline \multirow{2}{*}{$\begin{array}{l}\text { Parity/no. } \\
\text { of sons }\end{array}$} & \multicolumn{4}{|l|}{ Nepal } & \multicolumn{4}{|l|}{ India } & \multicolumn{4}{|c|}{ Bangladesh } \\
\hline & Modern & Traditional & Permanent & Temporary & Modern & Traditional & Permanent & Temporary & Modern & Traditional & Permanent & Temporary \\
\hline \multicolumn{13}{|l|}{ Parity 1} \\
\hline 0 sons (ref) & 1.00 & 1.00 & 1.00 & 1.00 & 1.00 & 1.00 & 1.00 & 1.00 & 1.00 & 1.00 & 1.00 & 1.00 \\
\hline 1 son & 1.24 & 0.85 & 1.23 & 1.18 & $1.33^{* *}$ & $1.15^{* *}$ & $1.73^{* *}$ & $1.19^{* *}$ & $1.31^{* *}$ & 0.97 & $2.02^{*}$ & $1.23^{*}$ \\
\hline \multicolumn{13}{|l|}{ Parity 2} \\
\hline 0 sons (ref) & 1.00 & 1.00 & 1.00 & 1.00 & 1.00 & 1.00 & 1.00 & 1.00 & 1.00 & 1.00 & 1.00 & 1.00 \\
\hline 1 son & $2.02^{* *}$ & 1.33 & $7.96^{* *}$ & 1.29 & $2.09^{* *}$ & $1.42^{* *}$ & $2.26^{* *}$ & $1.63^{* *}$ & $1.59 * *$ & 1.26 & $3.42^{* *}$ & $1.46^{* *}$ \\
\hline 2 sons & $3.73^{* *}$ & $2.33^{* *}$ & $18.85^{* *}$ & $1.75^{* *}$ & $2.94^{* *}$ & $1.62^{* *}$ & $2.46^{* *}$ & $1.72^{* *}$ & $1.40^{*}$ & 1.46 & $3.12^{* *}$ & $1.34^{*}$ \\
\hline \multicolumn{13}{|l|}{ Parity 3} \\
\hline 0 sons (ref) & 1.00 & 1.00 & 1.00 & 1.00 & 1.00 & 1.00 & 1.00 & 1.00 & 1.00 & 1.00 & 1.00 & 1.00 \\
\hline 1 son & $2.42^{* *}$ & 2.27 & $8.80^{* *}$ & 1.36 & $2.15^{* *}$ & $1.49 * *$ & $2.33^{* *}$ & $1.57^{* *}$ & $2.00 *$ & 1.56 & $3.86^{* *}$ & $1.77^{* *}$ \\
\hline 2 sons & $5.21^{* *}$ & 2.74 & $25.89^{* *}$ & $1.60^{*}$ & $3.83^{* *}$ & $1.73^{* *}$ & $4.58^{* *}$ & $1.67^{* *}$ & $2.09^{* *}$ & 1.62 & $5.92^{* *}$ & $1.72^{* *}$ \\
\hline 3 sons & $5.65^{* *}$ & 3.35 & $31.92^{* *}$ & 1.45 & $3.49^{* *}$ & $1.53^{*}$ & $4.19^{* *}$ & $1.47^{* *}$ & $2.05^{* *}$ & 1.04 & $3.67^{* *}$ & $1.70^{*}$ \\
\hline \multicolumn{13}{|l|}{ Parity $\geq 4$} \\
\hline 0 sons (ref) & 1.00 & 1.00 & 1.00 & 1.00 & 1.00 & 1.00 & 1.00 & 1.00 & 1.00 & 1.00 & 1.00 & 1.00 \\
\hline 1 son & $2.13^{* *}$ & 6.91 & $5.00^{* *}$ & 1.53 & $2.04^{* *}$ & 1.24 & $2.16^{* *}$ & $1.41 * *$ & $2.04^{* *}$ & 0.98 & $3.33^{*}$ & $1.57^{*}$ \\
\hline 2 sons & $3.53^{* *}$ & 6.39 & $12.06^{* *}$ & 1.39 & $2.98^{* *}$ & $1.35^{*}$ & $3.33^{* *}$ & $1.51^{* *}$ & $1.93^{* *}$ & 1.42 & $3.94^{*}$ & $1.62^{*}$ \\
\hline$\geq 3$ sons & $2.60 * *$ & 5.90 & $7.04^{* *}$ & 1.58 & $1.84^{* *}$ & 1.14 & $1.95^{* *}$ & $1.29^{*}$ & 1.43 & 0.94 & $3.35^{*}$ & 1.13 \\
\hline
\end{tabular}

${ }^{*} \mathrm{p}<.05 .{ }^{* *} \mathrm{p}<.01$. Notes: Number of respondents for each country and parity are the same as in Table 6, except for parity 3 in Bangladesh ( $\mathrm{N}=1,863$ ). Model controls for maternal education, employment, media exposure to family planning messages, residence, wealth quintile and participation in household decision making. The lowest two wealth quintiles are combined for Nepal because the number of observations for those quintiles is small. Base category is not practicing any form of contraception. ref=reference category. 
three countries, permanent method use (compared with no use) was strongly and positively associated with number of sons. For parities of 3 and higher, the relative risk ratio for permanent method use generally peaked among women with two sons and then declined.

The associations of parity and sex composition with use of a temporary method were much weaker than those for permanent methods. In most cases, the relative risk of using a temporary method was greater among women with at least one son than among those with no sons; however, there was no clear relationship between number of sons and use of temporary methods in Nepal. In North India, the number of sons was positively associated with use of a temporary or a permanent method at each parity, but in South India, Punjab and West Bengal, a positive association was observed only for permanent method use at parities 2 and 3 (not shown).

\section{CONCLUSION}

Prior research has shown that preference for a son has a considerable bearing on fertility desires and contraceptive use in South Asian countries. A major contribution of this paper is the comparative approach we used to examine the associations between son preference and reproductive outcomes, and to investigate whether use of family planning methods differs according to family size and sex composition. Using the latest Demographic and Health Survey data available for Nepal, India and Bangladesh, we found evidence that a strong preference for sons exists in all three countries (although there are regional differences within India). Our results suggest that parity and family sex composition strongly influence fertility desires and contraceptive behavior in South Asia.

In general, women with a greater number of sons were more likely to use contraceptives and less likely to want another child than were women with more daughters. An important finding is that parity and number of sons were strongly related to contraceptive use and fertility desires even after we controlled for socioeconomic and other factors, including education, employment, wealth, media exposure, women's participation in household decision making, and urban or rural residence. We argue that because the sex ratio at birth is biologically determined, these factors may partly control for sex-selective abortion. ${ }^{38}$

Our findings indicate that son preference is more prominent in Nepal and India than in Bangladesh. Within India, the relationship of parity and family composition to reproductive outcomes was stronger in North India and Punjab than in South India or West Bengal. But although women with fewer sons-regardless of parity or countrywere more likely to want another child and less likely to use contraceptives than were women without a son, our data also suggest that many women, especially those in Bangladesh, want to have a daughter after having a son. An earlier study suggested that women in Bangladesh want to have at least one daughter, but not before having two sons. ${ }^{27}$ In India, $74 \%$ of women and $65 \%$ of men report that their ideal family would include at least one daughter. ${ }^{36}$ The high proportions who want to have a daughter in spite of substantial son preference in the society may be due in part to the need to fulfill the Hindu religious obligation of kanyadaan (giving a daughter away at the time of her marriage without any expectation in return). This is an act that enables parents to acquire the highest level of merit. We did not find that preference for sons was greater in countries or regions where fertility has declined to relatively low levels. For example, South India, where the fertility rate is close to replacement level, does not exhibit greater levels of son preference than northern states, at least in terms of fertility desires and contraceptive use.

We observed a clear association of parity and number of sons with use of modern contraceptive methods, but not use of traditional methods. Because temporary methods enable couples to preserve their ability to have a son, those methods were more prevalent than permanent methods among women who had few sons or no sons. In contrast, reliance on permanent methods generally increased as women attained their desired family size and their desired number of sons, a pattern that was particularly strong in Nepal and India, where family planning programs have for many years emphasized permanent methods (especially female sterilization). Within India, the relationship of parity and sex composition with type of contraceptive method used was weaker in West Bengal and South India than in North India.

Our study has several limitations. First, we used crosssectional data, which allowed us to examine the associations between variables but not to show causality. Second, the surveys did not collect information on sex-selective abortion or feticide. Third, our analyses comparing modern with traditional method use and temporary with permanent method use did not account for potential unobserved heterogeneity related to service or method availability or to cultural acceptance of methods. However, we included several controls for socioeconomic factors, which tend to correlate with sex-selective abortion behavior, as well as with service availability and acceptance of family planning. Finally, it is important to note that because our data on desired fertility are self-reported, they could be affected by rationalization and may not correlate with fertility behavior.

The findings suggest that to maximize family planning acceptance, reduce fertility and counter the practice of sexselective abortion, programs need to target women on the basis of parity and family sex composition. More importantly, there is a need to reduce son preference. The desire for sons is embedded within the cultural fabric of South Asian societies, and reducing this preference will require altering social norms and people's attitudes, as well as improving women's status (particularly their access to higher education). ${ }^{39}$ Policies and programs should include mechanisms to make daughters more valuable to families and to remove gender differences within households through family planning, education and social programs. 
Such programs in South Asia need to recognize variations in women's status and son preference by sociocultural groups and regions, and be tailored accordingly.

\section{REFERENCES}

1. Arnold F, Choe MK and Roy TK, Son preference, the family-building process and child mortality in India, Population Studies, 1998, 52(3):301-315.

2. Clark S, Son preference and sex composition of children: evidence from India, Demography, 2000, 37(1):95-108.

3. Arnold F, Son preference in South Asia, in: Sathar ZA and Phillips JF, eds., Fertility Transition in South Asia, London: Oxford University Press, 2001, pp. 281-299.

4. Das Gupta M et al., Why is son preference so persistent in East and South Asia? A cross-country study of China, India, and the Republic of Korea, Policy Research Working Paper, Washington, DC: World Bank, 2003, No. 2,942.

5. Das Gupta M, Selective discrimination against female children in rural Punjab, India, Population and Development Review, 1987, 13(1): 77-100.

6. Stash S, Ideal-family-size and sex-composition preferences among wives and husbands in Nepal, Studies in Family Planning, 1996, 27(2): $107-118$

7. Burgess R and Zhuang J, Modernization and son preference in People's Republic of China, ERD Working Paper, Manila, Philippines: Asian Development Bank, 2002, No. 20.

8. Kingdon GG, The gender gap in educational attainment in India: How much can be explained? Journal of Development Studies, 2002, 39(2):25-53

9. Pande RP, Selective gender differences in childhood nutrition and immunization in rural India: the role of siblings, Demography, 2003, 40(3):395-418.

10. Timæus I, Harris K and Fairbairn F, Can use of health care explain sex differentials in child mortality in the developing world? in: Too Young to Die: Genes or Gender? New York: United Nations Department of Economic and Social Affairs, Population Division, 1998, pp. 154178

11. Behrman JR, Intra-household allocation of resources: Is there a gender bias? in: Too Young to Die: Genes or Gender? New York: United Nations Department of Economic and Social Affairs, Population Division, 1998, pp. 223-242.

12. Pelletier D, Malnutrition, morbidity and child mortality in developing countries, in: Too Young to Die: Genes or Gender? New York: United Nations Department of Economic and Social Affairs, Population Division, 1998, pp. 109-132.

13. Choe MK, Diamond I and Steele FA, Son preference, family building process and child mortality, in: Too Young to Die: Genes or Gender? New York: United Nations Department of Economic and Social Affairs, Population Division, 1998, pp. 208-222.

14. Kishor S, Gender differentials in child mortality: a review of evidence, in: Das Gupta M, Chen LC and Krishnan TN, eds., Women's Health in India: Risk and Vulnerability, Bombay: Oxford University Press, 1995, pp. 19-54.

15. Marcoux A, Sex differentials in undernutrition: a look at survey evidence, Population and Development Review, 2002, 28(2):275-284

16. Sommerfelt AE and Arnold F, Sex differentials in the nutritional status of young children, in: Too Young to Die: Genes or Gender? New York: United Nations Department of Economic and Social Affairs, Population Division, 1998, pp. 133-153.

17. Bhat PN and Zavier AJ, Fertility decline and gender bias in northern India, Demography, 2003, 40(4):637-657.

18. Bose $\mathrm{S}$ and Trent K, Socio-demographic determinants of abortion in India: a north-south comparison, Journal of Biosocial Science, 2006 , 38(2):261-282

19. Arnold F, Kishor S and Roy TK, Sex-selective abortions in India,
Population and Development Review, 2002, 28(4):759-785.

20. Sudha S and Rajan SI, Female demographic disadvantage in India 1981-1991: sex selective abortions and female infanticide, Development and Change, 1999, 30(3):585-618.

21. Yount KM, Langsten R and Hill K, The effect of gender preference on contraceptive use and fertility in rural Egypt, Studies in Family Planning, 2000, 31(4):290-300.

22. Bairagi R, Effects of sex preference on contraceptive use, abortion and fertility in Matlab, Bangladesh, International Family Planning Perspectives, 2001, 27(3):137-143.

23. Leone T, Matthews Z and Dalla Zuanna G, Impact and determinants of sex preference in Nepal, International Family Planning Perspectives, 2003, 29(2):69-75.

24. Das Gupta M and Bhat PN, Fertility decline and increased manifestation of sex bias in India, Population Studies, 1997, 51(3):307-315.

25. Visaria L and Visaria P, India's population in transition, Population Bulletin, 1995, 50(3):1-51

26. Poston DL, Jr., Son preference and fertility in China, Journal of Biosocial Science, 2002, 34(3):333-347.

27. Chowdhury MK and Bairagi R, Son preference and fertility in Bangladesh, Population and Development Review, 1990, 16(4):749-757.

28. Larsen U, Chung W and Das Gupta M, Fertility and son preference in Korea, Population Studies, 1998, 52(3):317-325.

29. Chung W and Das Gupta M, The decline of son preference in South Korea: the roles of development and public policy, Population and Development Review, 2007, 33(4):757-783.

30. Belanger D, Son preference in a rural village in North Vietnam, Studies in Family Planning, 2002, 33(4):321-334.

31. Case A and Deaton A, Consumption, health, gender, and poverty, Research Program in Development Studies Working Paper, Princeton, NJ USA: Research Program in Development Studies, Princeton University, 2002, No. 212

32. Stash S, Son preference and the dynamics of fertility decision-making among wives and their husbands in rural Nepal, in: Sathar ZA and Phillips JF, eds., Fertility Transition in South Asia, London: Oxford University Press, 2001, pp. 300-327.

33. Khan MA and Khanum PA, Influence of son preference on contraceptive use in Bangladesh, Asia-Pacific Population Journal, 2000, 15(3): 43-56.

34. Haughton J and Haughton D, Son preference in Vietnam, Studies in Family Planning, 1995, 26(6):325-337.

35. Nepal Ministry of Health and Population (MOHP), New ERA and Macro International, Nepal Demographic and Health Survey 2006, Kathmandu, Nepal: MOHP, New ERA and Macro International, 2007.

36. International Institute for Population Sciences (IIPS) and Macro International, National Family Health Survey (NFHS-3), 2005-2006: India, Mumbai, India: IIPS, 2007.

37. National Institute of Population Research and Training (NIPORT), Mitra and Associates, and ORC Macro, Bangladesh Demographic and Health Survey 2004, Dhaka, Bangladesh and Calverton, MD, USA: NIPORT, Mitra and Associates, and ORC Macro, 2005.

38. Mishra V, Roy TK and Retherford RD, Sex differentials in childhood feeding, health care, and nutritional status in India, Population and Development Review, 2004, 30(2):269-296.

39. Pande RP and Astone NM, Explaining son preference in rural India: the independent role of structural versus individual factors, Population Research and Policy Review, 2007, 26(1):1-29.

\section{RESUMEN}

Contexto: Muchos países en el Sur de Asia, incluidos Bangladesh, India y Nepal, demuestran una fuerte preferencia cultural por los hijos varones, lo cual puede influir en los deseos de fecundidad y el uso de anticonceptivos. 
Métodos: Datos de Encuestas de Demografía y Salud de mujeres casadas, no embarazadas entre 15-49 años de edad y que habian tenido al menos un hijo, fueron utilizados para examinar la relación de paridad y el número de hijos varones con los resultados reproductivos en Bangladesh, India y Nepal. Los resultados de interés fueron el deseo por tener otro hijo, el uso de anticonceptivos y el tipo de anticonceptivos (modernos vs. tradicionales, temporales vs. permanentes). Las razones de momios y las razones de riesgo relativo se calcularon usando regresión logística binaria y multinomial.

Resultados: En general, el deseo de tener otro hijo disminuyó, y el uso de anticonceptivos aumentó, conforme el número total de hijos y el número de hijos varones aumentó. Estas asociaciones fueron más prominentes en Nepal e India que en Bangladesh. Por ejemplo, comparadas con mujeres que tenían tres hijas y ningún hijo varón, las probabilidades de usar anticonceptivos en mujeres con dos hijos varones y una hija, fueron de 4.8 en Nepal, 3.5 en India y 2.0 en Bangladesh. Las asociaciones de paridad y el número de hijos con los resultados reproductivos fueron generalmente más fuertes en las estadas del norte de India, que en el Sur de India o West Bengal.

Conclusiones: La preferencia por los hijos continúa en los tres países y tiene una influencia importante en el comportamiento reproductivo. Reducir esta preferencia requeriría un cambio en las normas y actitudes sociales de las personas y una mejora en la condición de las mujeres.

\section{RÉSUMÉ}

Contexte: Beaucoup de pays d'Asie du Sud, y compris le Népal, l'Inde et le Bangladesh, présentent une forte préférence culturelle pour les fils, susceptible d'influencer les désirs de féc ondité et la pratique contraceptive.
Méthodes: Les données d'Enquête démographique et de santé relatives aux femmes mariées non enceintes de 15 à 49 ans mères d'au moins un enfant ont servi à examiner la relation entre parité et nombre de fils et les issues génésiques au Népal, en Inde et au Bangladesh. Les issues d'intérêt étaient le désir d'avoir encore un enfant, la pratique contraceptive et le type de contraceptif utilisé (moderne ou traditionnel, temporaire ou permanent). Les rapports de probabilités et rapports de risques relatifs ont été calculés par régression logistique binaire et multinomiale.

Résultats: En général, le désir d'avoir encore un enfant paraît moindre, et la pratique contraceptive supérieure, à mesure que le nombre d'enfants et le nombre de fils augmentent. Ces associations sont plus prononcées au Népal et en Inde qu'au Bangladesh. Ainsi, par rapport aux femmes mères de trois filles mais d'aucun fils, le rapport de probabilités de la pratique contraceptive parmi les femmes mères de deux fils et une fille est de 4,8 au Népal, 3,5 en Inde et 2,0 au Bangladesh. En Inde, les associations entre parité/nombre de fils et issues génésiques sont plus fortes dans les etats du nord que dans le sud et le Bengale occidental.

Conclusions: La préférence des fils demeure répandue dans les trois pays et exerce une influence majeure sur les comportements génésiques. La réduction de cette préférence exigerait un changement des normes sociales et des attitudes personnelles, ainsi qu'une amélioration de la condition féminine.

\section{Acknowledgment}

Support for this research was provided by the United States Agency for International Development through the MEASURE DHS project (\#GPO-C-00-03-00002-00).

Author contact: anuja.jayaraman@gmail.com 